\title{
DISPARITY IN LITERACY OF MUSLIM POPULATION IN RAJASTHAN STATE, INDIA: A SPATIAL ANALYSIS
}

\author{
Nafeesa Kayamkhani ${ }^{1}$ and Shagufta Saify ${ }^{2}$ \\ ${ }^{1}$ Research Scholar, Department of Geography, \\ Mohanlal Sukhadia University, Udaipur, Rajasthan, India \\ ${ }^{2}$ Assistant Professor (Geography), Govt. College Jhadol, (Udaipur) Rajasthan, India \\ Email: nafisakayamkhani@gmail.com, rangshagufta@gmail.com
}

\begin{abstract}
Literacy is one of the important demographic elements, which acts as a catalyst for social upliftment enhancing the returns on investments made in almost every aspects of development efforts, be it population control, health, hygiene, empowerment of women and weaker sections of the society. The present paper aims to study the rural-urban disparity of literacy of Muslim Population in Rajasthan. For the measurement of disparity in literacy of Muslim Population using Sopher's Disparity Index (1974 employed). The study results that the total literacy rate of Muslim population is 62.67 percent where the total literacy rate of state is 66.10 percent. Urban Muslims literacy rate is higher than rural in the state of Rajasthan.
\end{abstract}

Key words: Disparities, Literacy, Muslims, Rural, Urban

\section{Introduction}

According to the primary census of India, 2011 "A person aged 7 years and above who can both read and write with understanding in any language was taken as literate. A person, who can only read but cannot write, is not literate." 'Literacy is the ability to identify, understand, interpret, create, communicate and compute using printed and written materials associated with varying contexts. Literacy involves a continuum of learning in enabling individuals to achieve his or her goals, develop his or her knowledge and potential and participate fully in community and wider society' (UNESCO). Educational backwardness of Indian Muslims should be attributed not to any 'religious fanaticism' or 'minority complex' but to the small size of the middle class whose members can be expected to seek educational opportunities (Ahmed, 1981). Lack of adequate number of schools and infrastructural facilities in the Muslim dominated areas is the major cause of educational backwardness of this community (GOI, 2006). 'IQRA' the first word of Holy Quran word refers to the process of Reading. The Prime Minister's High Level Committee (Sachar Committee) on the Social, Economic and Educational Status of the Muslim Community of India was set up in March 2005 with the main objective of assessing the social, economic and educational status of Muslims in the states, regions, districts and blocks they live in, their livelihood activities, their levels of socio-economic development and asset base and income levels relative to other groups. The Report of the Committee, submitted in 2006, has become a landmark in documenting the social, economic and educational status of Muslims. "The mechanisms to ensure equity and equality of opportunity to bring about inclusion should be such that diversity is achieved and at the same time the perception of discrimination is eliminated. This is only possible when the importance of Muslims as an intrinsic part of the diverse Indian social mosaic is squarely recognized" (SCR, p. 238).

\section{Objectives}

- To calculate the total literacy rate of Muslim Population in Rajasthan.

- To examine sex wise rural-urban literacy rate of Muslim Population of Rajasthan.

- To analyze the rural-urban disparities in Literacy of Muslim Population in term of total literacy, sex wise literacy in Rajasthan.

\section{Data and Methods}

The present paper is entirely based on the secondary sources of data collected from Census of India publication and Statistical Abstract of Rajasthan, 2011. Literacy rate has been calculated by using the following formula: 
For the measurement of rural-urban disparity in literacy of Muslim Population, Sopher's Disparity Index (1974) modified by Kundu and Rao (1983) has been employed:

$$
D s=\log (X 2 / X 1)+\log (200-X 1) /(200-X 2)
$$

$\mathbf{X} \mathbf{2}$ is considered for Urban and $\mathbf{X} \mathbf{1}$ for rural literacy rates.

District wise disparity in Muslim's literacy has been shown by Choropleth maps.

\section{RESULTS AND DISCUSSION}

\section{Total Literacy Rate of Muslim Population in Rajasthan 2011}

Literacy level of Muslims differs from one district to another and from one geographical region to another. As per Table 1 the three southern districts Dungarpur, Banswara and Udaipur has very high level of literacy rate in term of Muslim population. Whereas the western three districts that touch international boundary has the lowest rate of Muslim literacy. As per above discussion: 1). the distribution of Muslim population and the total literacy rate of Muslim shows negative correlation. The western districts having the highest Muslim population shows the lowest rate of Muslim Literacy and vise-versa. 2). As we move from south- east part of the Rajasthan to western side the literacy rate of Muslim population is found declined.

Table 01: Total Muslim Literacy Rate of Muslim Population in Rajasthan-2011

\begin{tabular}{|l|l|c|l|}
\hline \multicolumn{1}{|c|}{$\#$} & \multicolumn{1}{c|}{ Category } & Literacy Rate (\%) & \multicolumn{1}{|c|}{ Name of Districts Under the category } \\
\hline 1. & Very High & Above 78 & Dungarpur, Banswara, Udaipur \\
\hline 2. & High & $68-78$ & $\begin{array}{l}\text { Sirohi, Rajsamand, Bhilwara, Chittogarh, Baran, Kota, } \\
\text { Jhalawar, Pratapgarh, Bundi, Jaipur }\end{array}$ \\
\hline 3. & Moderate & $58-68$ & $\begin{array}{l}\text { Pali, , Nagaur, Ajmer, Dausa, Sawai Madhopur, } \\
\text { Dholpur, Sikar, Jhunjhunu, Tonk, Karauli }\end{array}$ \\
\hline 4. & Low & $48-58$ & $\begin{array}{l}\text { Jodhpur, Bikaner, Hanumangarh, Churu, Ganganagar, } \\
\text { Alwar, Bharatpur. }\end{array}$ \\
\hline 5. & Very low & Below 48 & Jaisalmer, Barmer, Jalor \\
\hline
\end{tabular}

Source: Calculated from census of Rajasthan, 2011

\section{Rural-Urban Literacy Rate of Muslim Population in Rajasthan-2011}

Urban literacy level is high in the state of Rajasthan as compared to rural literacy. There are five districts which have higher literacy level than state average urban literacy level. As compared to the rural literacy among Muslims in the state, the urban Muslim literacy rate is much better due to awareness, easy access and the facilities are good in cities.

Table 02: Urban Literacy Rate of Muslim Population in Rajasthan-2011

\begin{tabular}{|l|l|c|l|}
\hline$\#$ & Category & Literacy Rate (\%) & \multicolumn{1}{|c|}{ Name of Districts Under the category } \\
\hline 1. & Very High & Above 81 & Dungarpur, Banswara, Udaipur, Rajsamand Pratapgarh \\
\hline 2. & High & $73-81$ & $\begin{array}{l}\text { Sirohi, Bhilwara, Chittogarh,, Baran, Kota, Jhalawar, } \\
\text { Bundi }\end{array}$ \\
\hline 3. & Moderate & $66-73$ & $\begin{array}{l}\text { Pali, Jalor, Ajmer, Jaipur, Dausa, Sawai Madhopur, } \\
\text { Dholpur, }\end{array}$ \\
\hline 4. & Low & $61-66$ & $\begin{array}{l}\text { Jodhpur, Jaisalmer, Barmer, Nagaur, Sikar, Jhunjhunu, } \\
\text { Ganganagar, Alwar, Tonk }\end{array}$ \\
\hline 5. & Very low & Below 61 & Bikaner, Hanumangarh, Churu, Bharatpur, Dhaulpur \\
\hline
\end{tabular}

Source: Calculated from census of Rajasthan, 2011

According to the census 2011 urban literacy rate was very high (Above 81 percent) in Dungarpur, Banswara, Udaipur, Rajsamand Pratapgarh (Table 2) and very low (Below 61 percent) in Bikaner, Hanumangarh, Churu, Bharatpur, Dhaulpur (Fig 1). In 2011 rural literacy rate was very high (Above 71 percent) in Dungarpur, Banswara, Udaipur, Baran, Kota (Table 3) and very low (Below 43 percent) in Bikaner, Jodhpur Jaisalmer, Barmer, Jalor (Fig.1). Rural as well as urban literacy rate of Muslim population is higher in southern districts of the state. Banswara gets the highest position in the state with 87.66 percent as urban literacy rate and 83.04 rural literacy rates (Fig.1). It is due to high rate of Muslim male migration towards gulf countries and remittance uplift the economic condition of the Muslims and initiates the establishment of private schools organized by the community people. 


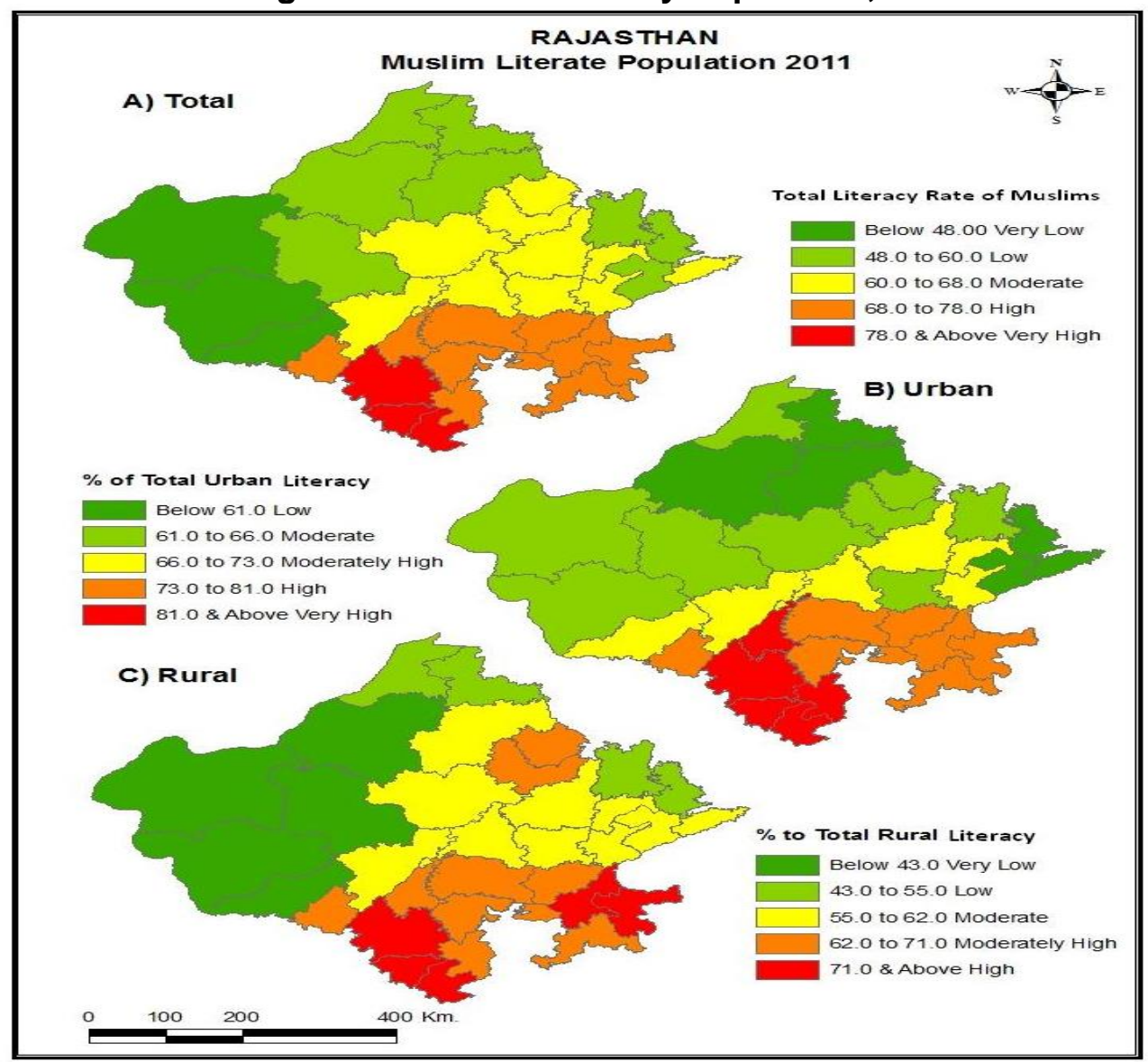

Table 03: Rural Literacy Rate of Muslim Population in Rajasthan-2011

\begin{tabular}{|l|l|c|l|}
\hline$\#$ & Category & Literacy Rate (\%) & Name of Districts Under the category \\
\hline 1. & Very High & Above 71 & Dungarpur, Banswara, Udaipur, Baran, Kota \\
\hline 2. & High & $62-71$ & $\begin{array}{l}\text { Sirohi, Bhilwara, Chittogarh, Tonk, Jhalawar, } \\
\text { Rajsamand, Pratapgarh, Sikar, Jhunjhunu, Bundi }\end{array}$ \\
\hline 3. & Moderate & $55-62$ & $\begin{array}{l}\text { Pali, Ajmer, Nagaur, Jaipur, Dausa, Sawai Madhopur, } \\
\text { Dholpur, Karauli, , Churu }\end{array}$ \\
\hline 4. & low & $43-55$ & Ganganagar, Alwar, Bharatpur, Hanumangarh, \\
\hline 5. & Very low & Below 43 & Bikaner, Jodhpur Jaisalmer, Barmer, Jalor \\
\hline
\end{tabular}

Source: Calculated from census of Rajasthan, 2011

\section{Sex wise Rural-Urban Literacy Rate}

In term of rural-urban male literacy, southern districts that is in Udaipur, Banswara, Dungarpur, Pratapgarh, Baran, Rajsamand and Kota shows highest rate. Whereas the central desert region followed by northern part of Jaisalmer, Barmer, Jodhpur, Nagaur, Sikar, Jhunjhunun, Jaipur, Alwar shows low literacy rate. The gap between rural - urban literacy rates for male is found 4 percent. The economic backwardness, difficult accessibility, scarcity of transportation is the main reason behind it.

Table 04: Rural Male Literacy Rate 2011

\begin{tabular}{|l|l|c|l|}
\hline \#. & Category & Range of Population (\%) & Name of Districts under the Category \\
\hline 1. & Very Low & Below 61.0 & $\begin{array}{l}\text { Ganganagar, Bikaner, Jaisalmer, Barmer, } \\
\text { Jodhpur, Jalor, }\end{array}$ \\
\hline 2. & Low & 61.0 to 71.0 & Hanumangarh, Bharatpur, \\
\hline 3. & Moderate & 71.0 to 78.0 & $\begin{array}{l}\text { Churu, Nagaur, Pali, Jaipur, Alwar, Dausa, } \\
\text { Tonk, Sawai Madhopur, Karauli, Dhaulpur }\end{array}$ \\
\hline 4. & High & 78.0 to 85.0 & $\begin{array}{l}\text { Jhunjhunun, Sikar, Ajmer, Rajsamand, } \\
\text { Bhilwara, Barmer, Chittaurgarh, Dungarpur, } \\
\text { Pratapgarh, Bundi, Jhalawar }\end{array}$ \\
\hline 5. & Very High & 85.0 \& Above & Udaipur, Bnaswara, Baran, Kota \\
\hline
\end{tabular}

Source: Calculated from census of Rajasthan, 2011 
Table 05: Urban Male Literacy Rate 2011

\begin{tabular}{|l|l|c|l|}
\hline$\#$ & Category & Range of Population (\%) & Name of Districts under the Category \\
\hline 1. & Very Low & Below 74.0 & $\begin{array}{l}\text { Ganganagar, Hanumangarh, Bikaner, Churu, } \\
\text { Bharatpur, Karauli, Dhaulpur, Tonk }\end{array}$ \\
\hline 2. & Low & 74.0 to 79.0 & $\begin{array}{l}\text { Jaisalmer, Barmer, Jodhpur, Nagaur, Sikar, } \\
\text { Jhunjhunun, Jaipur, Alwar }\end{array}$ \\
\hline 3. & Moderate & 79.0 to 84.0 & Jalor, Pali, Ajmer, Dausa, Sawai Madhopur \\
\hline 4. & High & 84.0 to 89.0 & $\begin{array}{l}\text { Bhilwara, Bundi, Chittaurgarh, Kota, Baran, } \\
\text { Jhalawar }\end{array}$ \\
\hline 5. & Very High & 89.0 \& Above & $\begin{array}{l}\text { Sirohi, Udaipur, Rajsamand, Dungarpur, } \\
\text { Banswara, Pratapgarh }\end{array}$ \\
\hline
\end{tabular}

Source: Calculated from census of Rajasthan, 2011

Table 06: Rural Female Literacy Rate 2011

\begin{tabular}{|c|l|c|l|}
\hline$\#$ & Category & Range of Population (\%) & Name of Districts under the Category \\
\hline 1. & Very Low & Below 29.0 & Bikaner, Jaisalmer, Barmer, Jodhpur, Jalor, \\
\hline 2. & Low & 29.0 to 38.0 & Ganganagar, Alwar, Bharatpur, \\
\hline 3. & Moderate & 38.0 to 48.0 & $\begin{array}{l}\text { Hanumangarh, Churu, Nagaur, Pali, } \\
\text { Rajsamand, Ajmer, Jaipur, Tonk, Dausa, } \\
\text { Sawai Madhopur, Karauli, Dhaulpur }\end{array}$ \\
\hline 4. & High & 48.0 to 57.0 & $\begin{array}{l}\text { Jhunjhunun, Sikar, Sirohi, Bhilwara, } \\
\text { Chittaurgarh, Bundi, Pratapgarh, Jhalawar }\end{array}$ \\
\hline 5. & Very High & 57.0 \& Above & Udaipur, Dungarpur, Banswara, Kota, Baran \\
\hline
\end{tabular}

Source: Calculated from census of Rajasthan, 2011

Table 07: Urban Female Literacy Rate 2011

\begin{tabular}{|c|l|c|l|}
\hline$\#$ & Category & Range of Population (\%) & Name of Districts under the Category \\
\hline 1. & Very Low & Below 48.0 & $\begin{array}{l}\text { Churu, Bikaner, Jaisalmer, Alwar, Bharatpur, } \\
\text { Karauli }\end{array}$ \\
\hline 2. & Low & 48.0 to 52.0 & $\begin{array}{l}\text { Ganganagar, Hanumangarh, Jhunjhunun, } \\
\text { Sikar, Nagaur, Barmer, Dhaulpur }\end{array}$ \\
\hline 3. & Moderate & 52.0 to 61.0 & $\begin{array}{l}\text { Jodhpur, Pali, Jalor, Jaipur, Tonk, Dausa, } \\
\text { Sawai Madhopur }\end{array}$ \\
\hline 4. & High & 61.0 to 73.0 & $\begin{array}{l}\text { Ajmer, Bhilwara, Chittaurgarh, Bundi, Kota, } \\
\text { Baran, Sirohi }\end{array}$ \\
\hline 5. & Very High & 73.0 \& Above & $\begin{array}{l}\text { Rajsamand, Udaipur, Dungarpur, Banswara, } \\
\text { Pratapgarh, Jhalawar }\end{array}$ \\
\hline
\end{tabular}

Source: Calculated from census of Rajasthan, 2011

The gap between rural - urban literacy rates for female is found around 13 percent. Western part of Rajasthan shows very low rural - urban female literacy rate. In Churu, Bikaner, Jaisalmer, Alwar, Bharatpur and Karauli also shows very low urban female literacy rate. Highest rural - urban female literacy rate calculated in Udaipur, Dungarpur, Banswara, Kota, Baran, Rajsamand, Pratapgarh and Jhalawar.

\section{Rural-Urban Disparity of Muslim Literacy}

The urban-rural differential in Muslim literacy is marked with notable variation in its distribution among the districts of Rajasthan state. The only Four districts (Jaisalmer, Jodhpur Barmer, Jalor) have much higher general rural-urban disparity higher than that in Rajasthan and very low (Table 8) in Churu, Jhunjhunu, Sikar, Karauli, Dhaulpur.

Table 08: Rural-Urban Disparity of Muslim Literacy 2011

\begin{tabular}{|c|l|c|l|}
\hline$\#$ & Category & Range of Population (\%) & Name of Districts under the Category \\
\hline 1. & Very Low & Below -0.01 & Churu, Jhunjhunu, Sikar, Karauli, Dhaulpur \\
\hline 2. & Low & -0.01 to 0.07 & $\begin{array}{l}\text { Nagaur, Bhilwara, Kota, Baran, Bharatpur, Tonk, } \\
\text { Banswara }\end{array}$ \\
\hline 3. & Moderate & 0.07 to 0.13 & $\begin{array}{l}\text { Hanumangarh, Pali, Sirohi, Udaipur, Dungarpur, } \\
\text { Pratapgarh, Chittaurgarh, Bundi, Jhalawar, Ajmer, } \\
\text { Jaipur, Alwar, Dausa, Sawai Madhopur, }\end{array}$ \\
\hline 4. & High & 0.13 to 0.20 & Rajasmand, Ganganagar, Bikaner \\
\hline 5. & Very High & $0.20 \&$ Above & Jaisalmer, Jodhpur Barmer, Jalor, \\
\hline
\end{tabular}

Source: Calculated from census of Rajasthan, 2011 


\section{Conclusion}

The Muslims are the only religious group who has the literacy rate below to state's average. Literacy rates are particularly low in those districts wherein the high concentration of Muslim population is observed. Urban literacy rate is higher than rural literacy rate in the state of Rajasthan. The variations in their literacy rates are largely an outcome of their geographical positioning, economic activity, need for education and social structure. Rural Muslims are marginalized, small farmers or self-employed artisans, skilled workers, tailors, retailers and in such other professions which do not require a person to be literate. Therefore, literacy rate of rural area is lower than urban area. The observation also leads to the conclusion that, four districts of the western part, namely Jaisalmer, Barmer, Jalor and Bikaner show the highest urban- rural differential in literacy of Muslims. This is partly due to unfavorable geographical factors (like rugged terrain, infertile soil, extreme climate-high temperature, low amount of rainfall etc.) and partly due to low level of urbanization, extreme poverty, lack of educational facilities and other social amenities.

\section{References}

1. Agarwal, A.K. and P.L. Hazarika (2002) Regional Disparities in Economic Development of Assam: A District Level Study. Indian Journal of Regional Science, XXXIV.

2. Ahmed, I. (1981) "Muslim Educational Backwardness: An Inferential Analysis", Economic and Political Weekly, 16(36)1461.

3. Ali. S.M. (1971) Muslim Education in Bengal 1837-1937, Islamic Studies, Vol. 10, No. 3 September 1971: 181-199.

4. Bandyopadhyaye. D. (2002) Madrasa Education and the Condition of Indian Muslim, Economic and Political Weekly, April 20, 2002.

5. Census of India (2011) Metadata 2011.

6. Engineer A.A. (2001) Muslims and Education, Economic and Political Weekly, August 25, 2001.

7. GOI (2006) Social, Economic and Educational Backwardness of Muslims in India: A Report, Report of the Prime Minister's High Level Committee, Government of India, New Delhi: 6388.

8. Jaglan, M.S. and Sindhu, R. (2008) "Regional Dimensions and Determinants of Gender Disparity in Educational Attainment in Rural Haryana", Population Geography, Vol.30:122.

9. Khan, A.Q. (2004) "Regional Imbalances and Changing Pattern of literacy in Jammu \& Kashmir State (1961-2001)", Population Geography, Vol.26:1-2.

10. Ojha A. (2016) Rural Urban Regional Disparity Pattern of Literacy in Rajasthan State, India, Journal of Global Resource. Vol. 2 January 2016:87-93.

11. Rajendra Sachar Committee Report. (2006) Social-Economic and Educational Status of the Muslims Community of India.

12. Roy \& Mondal. (2015) Rural Urban Disparity of Literacy in Murshidabad District, WB, India, International Research Journal of Social Sciences. Vol.4 (7):19-23.

13. Roy. S. (2012) Regional Disparities in Growth and Human Development in India. Institute for Studies in Industrial Development .Working Paper No.2012/05.

14. Siddiqui S. (2011) Regional Analysis of Urban Rural differentials in literacy of Employment in Uttar Pradesh, India, Journal of Geography and Regional Planning, Vol. 4. 5.

15. Sopher D.E. (1974) Measurement of Disparity, the Professional Geographer 26(4):380-392.

16. UNESCO. (2005) Aspects of Literacy Assessment: Topics and issues from the UNESCO Expert Meeting, 10-12 June, 2003.

17. Wilkinson, S. (2007) "A Comment on the Analysis in Sachar Report", Economic and Political Weekly, Vol. XLII, No. 10, March 11-16: 832-836. 